10.2478/genst-2018-0002

\title{
IMPRESSIVE WOMEN IN THE LATEST PRODUCTIONS SET IN J. K. ROWLING'S WIZARDING WORLD
}

\author{
LAURA MĂCINEANU \\ West University, Timișoara \\ 4, V. Pârvan Blvd, 300223 Timişoara, Romania \\ laura_macineanu@yahoo.com
}

\begin{abstract}
As J.K. Rowling continues to develop the fictional universe that has brought her fame, an already extensive gallery of female characters has been enriched with the portraits of some memorable and complex women. Her most recent heroines hold positions of power previously held only by men in the Harry Potter series or prove to be quite a match for their male counterparts. This paper proposes an analysis of the most important female characters in Harry Potter and the Cursed Child (July 2016) and Fantastic Beasts and Where to Find Them (November 2016).
\end{abstract}

Key words: archetypes, empowered women, fantasy literature, maturity, stereotypes.

\section{Introduction}

The well-known author of the seven-volume Harry Potter series, J.K Rowling is also recognised as the creator of some of the most memorable female characters in recent fantasy literature. Although the number of male characters in her fantasy books (which include the protagonist and the antagonist) surpasses that of the women, characters like Hermione Granger, Luna Lovegood, Molly Weasley or Professor Minerva MacGonagall stand out in the economy of the novels and, even more, have become role models for fans of the series. The author herself is proud of her achievement in creating such complex characters, as she declared in an interview for a documentary realised by Warner Bros - The Women of Harry Potter:

I'm a female writer and, what's interesting about the Wizarding World is, when you take physical strength out of the equation, a woman can fight just the same as a man can fight, a woman can do magic just as 
powerfully as a man can do magic and I consider that I've written a lot of well-rounded female characters in these books. (Rowling for Warner Bros, 2011)

Written after a substantial time gap, the new productions bearing the signature of J.K. Rowling raise interest not just because the author has decided to present them via different media - stage play and motion picture, but also because she seems to bring even more female characters centre stage in her stories. The author has created empowered women placed in important hierarchical positions, produced two daunting female antagonists and explored various themes connected to femininity - motherhood, sisterhood, romantic love, married life. There is a variety of archetypes to which her female characters can be connected: the Holy Mother, the Earth Mother, the Terrible Mother, the Ruler, the Wise Woman, the Female Warrior or the Temptress. The importance Rowling attaches to the feminine element in her latest stories is obvious, making an analysis of these heroines both interesting and worthwhile.

\section{Female Characters in Harry Potter and the Cursed Child}

Titled as "the eighth Harry Potter story", Harry Potter and the Cursed Child is a two-part play written by Jack Thorne, based on a story by J.K. Rowling, John Tiffany and Jack Thorne. The original script, released in July 2016, narrates the adventures of Albus, Harry Potter's youngest son, and Scorpius, Draco Malfoy's only son, being set nineteen years after the events in Harry Potter and The Deathly Hallows. As this is practically Rowling's world, one that she has invented from scratch and on which she has a large amount of data, we may assume that she had the decisive word in outlining the story and its characters and that, therefore, the women in the play are representative of her vision of femininity.

One of the first issues to be noted is the placing of women in positions of power inside the hierarchy of the wizarding world, positions normally held by men in the book series. Hogwarts had a male dominated hierarchy in the Harry Potter books and the same was true of the Ministry of Magic. Rowling has made amends in the play, where Hermione Granger is the Minister for Magic, the highest authority in the wizarding world and Professor Minerva McGonagall is Headmistress of Hogwarts. In having Hermione interpreted by an actress of colour Rowling has reasserted not only women's right and capacity to occupy hierarchical positions, but also the importance of racial equality in the wizarding world. It is no accident that these two strong, complex women hold the two most important positions in Rowling's fictional universe. Fans and scholars have wondered 
whether in the future Hermione the student may follow in her teacher's footsteps, becoming a member of the teaching staff at Hogwarts. While the book series was still being published, Eliza T. Dresang (2002:241) found similarities between Minerva McGonagall and Hermione Granger, predicting that, Hermione may grow to be very much like her favourite teacher and even surpass her by being more multidimensional, more socially involved. Through their determination, responsibility, wisdom, courage and abilities both characters are perfect representatives of the Wise Woman archetype, with strong traces of the Female Warrior archetype. As Minister for Magic, Hermione retains the above-mentioned qualities and seems to be "the woman for the job". She reminds of an authoritative executive manager as she shouts to her secretary: "Ethel! Cancel the goblins." (Rowling, Thorne, Tiffany 2016:133). It is not surprising for readers of previous stories that Hermione knows how to exercise her authority and that she is aware of all the developments in the wizarding world and not only. She is also able to exercise control over Harry Potter, the head of the Magical Law Enforcement Department, and reprimand him for not completing his paperwork - an echo of so many situations in the books, when Hermione had to urge Harry and Ron to get their work done for school. She seems to have been devoting most of her time and energy to her job rather than to her family. Being a workaholic certainly fits the image of Hermione the student, obsessed with learning and aware of the necessity to work hard in order to achieve one's goals. However, we may detect her uneasiness, as she remarks to Harry:

You know, Ron says he thinks I see more of my secretary, Ethel, (she indicates off) than him. Do you think there's a point where we made a choice — parent of the year or Ministry official of the year? (Ibid.:24)

Unfortunately, we do not witness a lot of the decision-making process and we see even less of Minerva McGonagall's activity as Headmistress of Hogwarts. In fact, previous knowledge of the characters is essential in completing the audience's image of the two women. Hermione's involvement in the development of the story is not very substantial in the primary reality, were it not for her being a member of the party that goes in search of the two lost boys. She only accidentally influences events by hiding the Time Turner in her office, where Albus, Scorpius and Delphi are able to find it and retrieve it. It is unlikely, however, for a witch of her intelligence and abilities not to be able to hide the device more effectively. Hermione is actually reprimanded by McGonagall for keeping the device in her office. It is even more unlikely for such a perceptive and 
clever woman not to realise that the man she is talking to on the Ministry corridors is not her husband, but her nephew, under the effect of Polyjuice Potion.

Also leading to a certain diminishing of the stature of the two women are the scenes where they do not seem able to fully exercise their authority. Hermione is not able to preserve the order during one of the grand meetings she chairs at the Ministry of Magic and is "surprised" (Ibid.:145) to be able to silence the crowd with ease at the second meeting. Professor McGonagall, in turn, seems to lose her nerve when confronted with an anxious and overexcited Harry Potter and decides to obey his orders, even though reluctantly. The abrupt manner in which Harry addresses her would have provoked a strong reaction from the Minerva McGonagall we knew in the Harry Potter books. Kristina Grosspietsch believes this careless presentation of two of the most important female characters created by Rowling is due to the play actually being written by a man - Jack Thorne:

[...] we can tell it's written by a man when we shouldn't feel the writer's presence at all. The magical world we adore has suddenly been filtered through a particularly narrow male perspective [...] (Grosspietsch 2016)

The time travel theme that provides the driving engine for the play also allows us to see different hypostases of several characters previously known from the book series. It is interesting to see how the characters of Hermione Granger and Ron Weasley change as various alternative worlds are presented. In the primary, reality Hermione is Minister for Magic, a job that keeps her away from home most of the time, Ron is running his twin brothers' joke shop, Weasleys' Wizard Wheezes but is described as mostly focused on bringing up their two children, Rose and Hugo. He has developed quite a pot belly, as he loves eating. In fact, there are quite a few references to Ron eating in the most unsuitable places or having his clothes stained with food. He makes a lot of blunders and does some lame tricks but he is still kind-hearted, loyal and funny. In the first alternate reality, Ron is married to a former schoolmate, Padma Patil, who bosses him around. They have a son, Panju, who keeps getting into trouble and who scorns his father. His clothes are "spectacularly staid" and his side-parting is "super aggressive" (Rowling, Thorne, Tiffany 2016:73). He does not run the joke shop and is described as "not even an inch of the man he was" (74). Hermione, on the other hand, is single and works as Defence against the Dark Arts professor, which means that she now holds the most coveted and most demanding position at Hogwarts. Although she seems to be feared by her students, she is clearly very good at her job. In the second alternate reality, both Hermione and Ron are single and they both are members of the Resistance against Voldemort's 
totalitarian regime. While Hermione is presented as "magnificent looking", having the appearance of a "full warrior", which "rather suits her" (107), Ron "is slightly less good at the rebel look" (108), with his spiked hair and scruffy clothes. We learn that Hermione is "a wanted woman", but Ron is, as Professor Snape ironically puts it, "less wanted" (109). However, Ron bravely decides to remain by Hermione's side and surrender to the Dementors' kiss to ensure a better future. It is clear from the different hypostases of these two characters that they are happiest when they are together. But it is also obvious that Hermione is capable of succeeding in life and achieving an important position on her own, while Ron does not manage to reach his full potential without her.

Another very important aspect is the presence of Rowling's first female archenemy Delphini, a.k.a. Delphi. The illegitimate daughter of Voldemort and Bellatrix Lestrange, she is a prodigious witch, considering that she is in her early twenties and is self-taught. However, the importance of the part she plays is only revealed at a late point in the story. She is introduced as "a twenty-something, determined-looking woman" (Rowling, Thorne, Tiffany 2016:26) and appears to be a secondary character, one that, somehow, manages to be present at all the important points in the plot and virtually moves the plot forward through her interventions. Delphi suggests the course of action to the two protagonists without them even being aware of it, which proves she is manipulative and resourceful, but also highly intelligent and patient. In doing this, she becomes the perfect embodiment of the Temptress archetype. She also seems to have the despotic behaviour and outbursts of her father:

I am the new past. [...] I am the new future [...] I am the answer this world has been looking for. (Ibid.:131)

She is determined to single-handedly resurrect her father and almost succeeds. In the end, she is revealed as yet another of J.K. Rowling's orphans wishing to know the father she has never met, which offers depth and credibility to the character. One may also note that, despite being an outstanding Dark Lady in her own right, all of Delphini's actions are dictated by her longing for approval and acceptance from her father. Conversely, Voldemort acted in pursuit of his entirely selfish goals - absolute power and endless life.

One of the most impressive female characters, who actually never appears in the play and is described by her husband and her son, is Astoria Malfoy. She not only married one of the most conflicted characters in the Harry Potter series, Draco Malfoy, but also helped him see the errors of his ways and defy his parents to change the course of his life: 
You know what I loved most about your mother? She could always help me find light in the darkness. She made the world — my world, anyway — less [...] "murky.” (Ibid.:103)

Despite having a serious health condition that would ultimately cause her premature death, she insists on having a child to remain with his father when she is gone. Astoria is surely the person responsible for the upbringing of their son, Scorpius, as a sensitive, responsible person, the exact opposite of his father during his school years. In sacrificing her life for her family she reminds of Lily Potter, both being representatives of the Holy Mother archetype.

\section{Female Characters in Fantastic Beasts and Where to Find Them}

The original screenplay, entirely written by Rowling, and the homonymous film (the first instalment in a five-movie series) were released in November 2016. The story has its source in one of the books Rowling has written for charitable purposes and which bears the same title. With this story Rowling moves away from the British wizarding world and focuses on the magical community of New York in the 1920's and the inopportune arrival of the British magizoologist Newt Scamander with his case full of magical beasts. Prior to the publication of the original script, Rowling tried to familiarise readers with the American wizarding world by publishing various related stories on her website, Pottermore. That is where we can find out about the history of magic in North America, the MACUSA (the Magical Congress of the United States of America) or the Ilvermorny School of Witchcraft and Wizardry in Massachusetts. It is in these auxiliary stories that we encounter even stronger women holding important positions in the wizarding world.

The most influential female character in the film, whose biography is rendered in more detail on Pottermore, is Madam Seraphina Picquery, President of MACUSA and virtually the highest authority in the American magical community. As in the case of Hermione in Harry Potter and The Cursed Child, Rowling placed a woman of colour in the most important position of power. She is described as "a majestic-looking witch" (Rowling 2016:73), "her tone steely" (429), rarely light-hearted and obviously accustomed to being obeyed without question. Rowling informs us in the History of Magic in North America (2016) on Pottermore that she is "formidable and a strong leader" and one of the very few students to have ever been sorted into all four houses of Ilvermorny School. All these traits suggest her affiliation to the powerful archetype of the Ruler/the Queen, corresponding to a person dedicated to creating and preserving order and security in the community 
she is responsible for. In an interview Pottermore released, Carmen Ejogo talks about the character she interprets - Madam Picquery: she is a "woman of power who doesn't have to assert her authority", a complex, "nuanced" woman, who is "not two-dimensional and predictable", a conflicted character who is simply very good at hiding it. Unfortunately, we do not see enough of this character on screen to be able to infer more about her personality and future role in the development of the plot. Therefore, we must take this description for granted, until the publishing of the next screenplays allows a more informed opinion.

A woman who played a defining role in the history of magic in America was Isolt Sayre, founder of the Ilvermorny School of Witchcraft and Wizardry, whose story can be found only on Pottermore. Isolt, a witch of Irish descent, got to America aboard the Mayflower, fleeing her wicked aunt. Not only did she manage to settle down and start a family under highly adverse circumstances, but she laid the foundation for what would later become one of the best wizarding schools in the magical world. If we consider the fact that Hogwarts had four founders (Godric Gryffindor, Rowena Ravenclaw, Helga Hufflepuff and Salazar Slytherin), what this woman achieved single-handedly in a foreign and perilous realm so far away from home is impressive. Without receiving a formal magical education, she uses her intelligence, determination and courage to create a home away from home for herself and the loved ones. Rowling creates here a character who does not succeed through special skills and unique talents, but through being able to connect, empathise and offer help to anyone in need, sometimes even disregarding her own safety. Isolt thus demonstrates her affiliation to the archetype of the Holy Mother. Her story also constitutes proof that Rowling is indeed trying to place women in significant and influential positions in her fictional universe.

A detail coming to support this theory is the presence in the North American magical community of not one (as was Mr Ollivander in Harry Potter), but four famous wand makers, two of which were women. Rowling specifies in the History of Magic in North America (2016) on Pottermore that Shikoba Wolfe, of Choctaw descent, produced wands that were "extremely powerful, though difficult to master" (which says something about the abilities of the woman who crafted them), while Violetta Beauvais, the famous wand maker of New Orleans whose wands "took to Dark magic like vampires to blood" but were also used by some great American heroes, designed one of the wands used by Seraphina Picquery. 
Rowling creates another one of her memorable Dark Ladies in this story - Mary Lou Barebone. She is the founder and leader of the New Salem Philanthropic Society, a religious charitable organisation focused on feeding poor children and organising rallies to raise awareness about the existence of witches. Described as "a handsome midwestern woman in a 1920s version of Puritan dress, charismatic and earnest" (Rowling 2016:25), always dignified, there is more to Mary Lou Barebone than meets the eye. She has three adopted children who seem to be of uncertain descendance and whom she regularly beats.

Mary Lou stands on the landing overlooking the main church below. Seen from below, her figure is powerful, almost deified. Mary Lou turns back toward Credence and slowly, her face full of loathing, snaps the wand in two. As Modesty cowers, Credence begins to remove his belt. Mary Lou holds out her hand and takes it.

CREDENCE (pleading) Ma ...

MARY LOU I am not your ma! Your mother was a wicked, unnatural woman! (Ibid.:342)

This is the first time when Rowling creates a strong character so passionate about the fight against witchcraft, a "crime" of which the writer herself has been accused. From Pottermore we find out the reason for Mary Lou's attitude: she is a descendant of the Scourers, "wizarding mercenaries" who caught and sold other witches and wizards during the Salem trials. She not only believes in the existence of magic but wishes to eradicate it believing it to be a dark force, as this conviction was perpetuated in her family. She even wants to involve the media magnate Shaw in her crusade, in order to have him publish articles about the magical activities going on in New York. This speaks of her determination, intelligence and power of planning ahead. Mary Lou Barebone reminds of Petunia Dursley, but she takes hate towards witchcraft to a different level, which will eventually bring about her demise. Through her hypocrisy and cruelty she also resembles Dolores Umbridge, the infamous representative of the Ministry of Magic at Hogwarts. All the three women fit perfectly within the boundaries of the Terrible Mother archetype: Petunia Dursley proves to be quite a "terrible" mother for Harry Potter, Dolores Umbridge enjoys punishing her students and keeping them ignorant and defenceless, while Mary Lou Barebone cruelly mistreats her adoptive children.

Last but not least, Rowling introduces a sisters' duo as half of the story's quartet of protagonists. Porpentina and Queenie Goldstein almost equally share the screen with their male counterparts, Newt Scamander and the No-Maj Jacob Kowalski. It is not about a male protagonist 
and his companions; it is rather about four people who befriend and support one another. This is the first time Rowling explores the theme of sisterhood in such depth and it is a subject into which she has certainly brought her personal experience, as she herself has a sister. The Goldstein sisters, of Jewish descent, were orphaned from a young age and practically raised themselves. The connection between the two sisters is profound, as it has always been the two of them and the rest of the world. This is what makes Alison Vincent remark that "Fantastic Beasts and Where to Find Them has a strong chance of passing the Bechdel Test, something previous Potter films have only just about managed" (2016). Porpentina (Tina) is a former Auror who recently got demoted for causing exposure of the magical community while trying to prevent Mary Lou Barebone from beating her adoptive son. She is described by her sister as "the career girl" (Rowling 2016:153). Interestingly, she is not a highly skilled witch, but is courageous, determined to do her job well and to fight for what is right. She is rather reserved and protective of her sister, who is more lighthearted. Queenie is a lively, kind-hearted, highly gifted legilimens, who can read the whole story of a person's past, their deepest thoughts and feelings. However, her abilities are not exploited (perhaps not known) at MACUSA, where she has a menial job. She is described as blond, "the most beautiful girl ever to don witches' robes" (136) and is very much aware of this; she is one of very few sexualised women in Rowling's fictional world. While Tina, the Auror, represents the Female Warrior archetype, Queenie fits the archetype of the Earth Mother, offering empathy and warmth, as well as nourishment and shelter to the two male protagonists.

In fact, Queenie Goldstein is the only woman in Rowling's recent productions who is a very good (magical) cook and is preoccupied by fashion and light magazines, but is not very interested in acts of bravery or in constructing a career for herself. With Tina as an Auror, Hermione Granger as Minister for Magic or Ginny Potter as the sports editor for the Daily Prophet, the kitchen remains the domain of men. In Rowling's latest productions there are male characters that are deeply preoccupied by eating and/or cooking. Ron enjoys eating and presumably cooks, since he is in charge of raising his children, while in the Potters' home the kitchen is Harry's domain. Jacob Kowalski, the fourth member of the Fantastic Beasts quartet, is persistent in his plan to open his own bakery, where he could bake the kind of homemade pastries he enjoyed as a child. This reversal of the traditional gender roles adds comical flavour to the text.

\section{Conclusion}


As this paper has endeavoured to demonstrate, J.K. Rowling's latest productions offer a large array of complex female characters. Unlike the Harry Potter book series, both Harry Potter and the Cursed Child and Fantastic Beasts and Where to Find Them bring centre stage adult, mature women facing a different set of problems, often occupying hierarchical positions. Not only does the writer present women belonging to several archetypes, but these characters evolve and break stereotypes, becoming more than mere representations of these consecrated hypostases of the feminine. Future perspectives are also promising, as the latter production is the first in an ongoing series in which many other interesting female characters are expected to appear.

\section{References:}

Dresang, Eliza T. 2002. "Hermione Granger and the Heritage of Gender" in The Ivory Tower and Harry Potter. Perspectives on a Literary Phenomenon. Lana E. Whited (Ed.). Columbia: University of Missouri Press, pp.211-242.

Grosspietsch, Kristina. 2016. “'Harry Potter and the Cursed Child' Lets Down J.K. Rowling's Characters” in Mashable [Online]. Available:

http://mashable.com/2016/08/17/harry-potter-cursed-child-female-characters/\#cKwFuLLYDSq1 [Accessed 2017, May 2].

Rowling. J.K. 2016. History of Magic in North America. Pottermore Limited. [Online]. Available: https://www.pottermore.com/collection-episodic/history-of-magic-in-north-america-en [Accessed 2016, April 15].

Rowling, J.K.; Thorne, Jack; Tiffany, John. 2016. Harry Potter and the Cursed Child - Parts One and Two (Special Rehearsal Edition Script). Pottermore Limited. [Online]. Available: www.pottermore.com [Accessed 2017, March 5].

Rowling, J.K. 2016. Fantastic Beasts and Where to Find Them: The Original Screenplay. Pottermore Limited. [Online]. Available: www.pottermore.com [Accessed 2017, March 5].

Vincent, Alison. 2016. "Could Tina and Queenie Goldstein become Fantastic Beasts' Feminist Heroes?" in The Telegraph [Online]. Available: http://www.telegraph.co.uk/film/ fantastic-beasts-and-where-to-find-them/queenie-tina-feminism-sisters/ [Accessed 2017, May 2].

*** 2011. The Women of Harry Potter. Warner Bros. Entertainment Inc. [Online]. Available: https://www.youtube.com/watch?v=etNcsShL3F0 . [Accessed 2017, March 22]

*** 2016. The Fantastic Beasts interviews: commander-in-chief Carmen Ejogo. [Online]. Available: https://www.pottermore.com/news/fantastic-beasts-interview-series-carmen-ejogo [Accessed 2017, March 5]. 